\title{
The Effect of Insulin on the Uptake of Radioactive Labelled Plasma Triglycerides by Rat Tissue in Vivo*
}

\author{
F. Arnold Gries, Siegrried Potrhoff and Karu Jahrke \\ Second Medical Clinic and Policlinic, University of Düsseldorf, Germany (Director: Professor Dr. K.
} OBERDISSE)

Received November 29, 1966

Summary. The uptake of plasma lipids into tissue was studied in normal, starved, and alloxan-diabetic rats before and after treatment with insulin, using fat emulsion and rat chylomicrons labelled with radioactive triglyceride fatty acids. - Fifteen minutes after intravenous injection of fat emulsion $97 \%$ of the label was recovered in lipid extracts of 8 different tissues; $67 \%$ was recovered after injection of chylomicrons. Most of the lipid-extrac. table radioactivity was found in plasma, liver, and adipose tissue, the last containing about $20 \%$ of the injected dose. In diabetic rats the lipid uptake of the liver decreased by $20 \pm 29 \%$. This defect was not readily reversed by insulin. The uptake increased by $126 \pm 96 \%$ in the heart but returned to normal after treatment with insulin. In adipose tissue of diabetic rats the lipid uptake decreased by $80 \pm 10 \%$ or more. It was significantly stimulated 30 minutes after injecting 1 unit of insulin. The lipid uptake also decreased in adipose tissue of starved rats. In these animals it was not stimulated by insulin; however, it was stimulated with the administration of glucose. - The decrease of lipid uptake by adipose tissue was paralleled by a delayed elimination of lipid from blood plasma and vice versa. The experiments suggest that the defect of triglyceride metabolism in adipose tissue plays a major role in hyperlipaemia associated with decompensated diabetes mellitus.

Effet de l'insuline sur l'entrée des triglycérides du plasma, marqués par ${ }^{14} C$, dans divers tissus du rat in vivo.

Résumé. La captation tissulaire des lipides plasmatiques a été étudiée chez des rats normaux, à jeun et chez des rats rendus diabétiques par l'alloxane, avant et après traitement par l'insuline, au moyen d'une émulsion de graisse ou de chylomicrons de rat marqués par des acides gras radioactifs. - Quinze minutes après l'injection intraveineuse de l'émulsion de graisse, $97 \%$ de la radioactivité ont été retrouvés dans des extraits lipidiques de huit tissus différents, tandis que $67 \%$ ont été retrouvés après l'injection de chylomicrons. La plupart de la radioactivité lipo-soluble se trouvait dans le plasma, le foie et dans le tissu adipeux qui contenait environ $20 \%$ de la dose injectée. - Chez les rats diabétiques, la captation des lipides par le foie était diminuée de $20 \pm 29 \%$. Cette diminution n'a pas été normalisée rapidement par l'insuline. La captation augmentait de $126 \pm 96 \%$ dans le coeur, mais était ramenée à la normale par le traitement à l'insuline. Dans le tissu adipeux des rats diabétiques, la captation de lipides diminuait d'au moins $80 \pm 10 \%$.

* In part presented at the Fifth Congress of the International Diabetes Federation, Toronto 1964.
Celle-ci était augmentée significativement 30 minutes après l'injection d'une unité d'insuline. La captation lipidique diminuait aussi dans le tissu adipoux des rats à jeun. Chez ces animaux, elle n'était pas augmentée par l'insuline, mais bien par-l'administration de glucose. La diminution de la captation des lipides par le tissu adipeux était accompagnée par une élimination retardée des lipides du plasma sanguin et vice versa. Les investi. gations suggèrent que le défaut métabolique des triglycérides dans le tissu adipeux joue un rôle majeur dans l'hyperlipémie associée au diabète décompensé.

Wirkung von Insulin auf die Aufnahme radioaktiv markierter Plasmatriglyceride durch Rattengewebe in vivo.

Zusammenfassung. In Untersuchungen mit Fettemulsionen und Chylomikronen, bei denen Fettsäuren der Triglyceride radioaktiv markiert waren, wurde die Aufnahme von Plasma-Triglyceriden in Gewebe bei normalen, hungernden und alloxan-diabetischen Ratten vor und nach Insulininjektion gemessen. - 15 Minuten nach intravenöser Injektion der Fettemulsion wurden 97\% der Radioaktivität in Lipidextrakten acht verschiedener Organe wiedergefunden, während in gleichartigen Versuchen mit Chylomikronen nur $67 \%$ wiedergefunden wurden. Der Hauptanteil der lipidlöslichen Radioaktivität fand sich in Blutplasma, Leber und Fettgewebe; letzteres enthielt etwa $20 \%$ der injizierten Radioaktivität. Bei diabetischen Ratten war der Gehalt radioaktiver Lipide in der Leber um $20 \pm 29 \%$ verringert. Diese Verminderung der Lipidaufnahme wurde durch kurzdauernde Insulinbehandlung nicht normalisiert. Die Lipidaufnahme des Herzens war um $126 \pm 96 \%$ gesteigert und kehrte nach Insulinbehandlung zur Norm zurück. Die Aufnahme von Plasmalipiden in das Fettgewebe diabetischer Ratten war um $80 \pm 10 \%$ oder mehr vermindert und wurde durch Injektion von 1 Einheit kristallinem Insulin innerhalb 30 Minuten signifikant gesteigert. Auch bei hungernden Ratten war die Lipidaufnahme des Fettgewebes signifikant herabgesetzt. Bei diesen Tieren konnte sie nicht durch Injektion von Insulin, jedoch durch parenterale Zufuhr von Glucose signifikant stimuliert werden. - Die Verminderung der Lipidaufnahme des Fettgewebes ging mit einer verzögerten Elimination der markierten Triglyceride aus dem Blut einher und vice versa. Die Versuche lassen vermuten, daß Störungen des Triglyceridstoffwechsels im Fettgewebe eine entscheidende Rolle in der Pathogenese der Hyperlipämie des dekompensierten Diabetes mellitus spielen.

Key-words: diabetic hyperlipemia, chylomicrons, serum triglycerides, insulin, adipose tissue, metabolic effects 


\section{Introduction}

Hyperlipaemia associated with decompensated diabetes mellitus is characterized by an increase in triglycerides $(\mathrm{TG})^{1}$ and can be corrected by exogenous insulin [6]. It is generally accepted that lack of insulin induces mobilization of fat from adipose tissue stores. The fatty acids may be resynthetized to TG by the liver and released into the blood in increased amounts $[9,37]$, thus resulting in elevated plasma lipid levels. Such a correlation between endogenous TG synthesis and plasma TG concentration was suggested by experiments of ReAven et al. [23]. However, it was not confirmed by other investigators [29]. In addition, studies on normal human subjects demonstrated that an increased flow of dietary fat into the blood per se did not result in permanent elevation of blood lipids [7]. It may be suggested, therefore, that plasma TG levels are mainly determined by peripheral $T G$ uptake. Defects in peripheral TG metabolism have been discussed as pathogenetical factors in idiopathic hyperlipaemia [11]. They seem to play a role also in diabetic hyperlipaemia. In pancreatectomized dogs [35, 17], as well as decompensated diabetic human subjects [14], the half-life of injected TG-emulsions in the blood was consistently prolonged. It returned to normal after the administration of insulin, suggesting that diabetic hyperlipaemia may in part be due to a reversible impairment of peripheral TG uptake.

Direct evidence for such a mechanism has not been published, and the role of the various tissues - if any - is unknown. Therefore, the uptake of plasma TG by peripheral tissues has been studied in normal, alloxandiabetic, and starved rats before and after the administration of insulin, employing radioactive-labelled fat emulsion and rat chylomicrons.

\section{Materials and methods}

Sixty-eight male albino rats were taken from a Sprague Dawley strain (Bundesanstalt für Versuchstierzucht, Hannover, Germany). The body weight was 95-130 $\mathrm{g}$ except in rats used for the starvation studies, where body weight was $170-185 \mathrm{~g}$. The animals had free access to tap water and food (Altromin "R" from Altrogge, Lage/Lippe, Germany). Fasting animals were allowed tap water only. Diabetes mellitus was produced by intravenous injection of $80 \mathrm{mg}$ of alloxan (solution of $2 \mathrm{~g}$ per $100 \mathrm{ml}$ of water) per $\mathrm{kg}$ body weight. Eighty percent of the alloxan-treated rats developed diabetes within $3-5$ days, as indicated by a rise in blood glucose to over $300 \mathrm{mg}$ per $100 \mathrm{ml}$, elevation of plasma EFA from a normal level of $234 \mathrm{mg}$ per $100 \mathrm{ml}$ to $367 \mathrm{mg}$ per $100 \mathrm{ml}$, and acetonuria. The animals were used for the metabolic studies no earlier

1 Abbreviations : triglyceride(s) = TG; esterified fatty acids $=$ EFA; lipid-extractable radioactivity $=\mathrm{LER}$. than 2 days and no later than 5 days after developing diabetic symptoms.

Radioactive tracers: 1. Fat emulsion contained $10 \%$ of cottonseed oil, $5 \%$ of sorbitol, and $1.5 \%$ of purified soybean phosphatides in distilled water (B. Braun, Melsungen, Germany). Triglycerides had been labelled by adding glycerol-tri $\left(1-{ }^{14} \mathrm{C}\right.$-palmitate) before being emulsified. The size of the lipid particles was $0.2-0.4 \mu$, the radioactivity was $7.68 \times 10^{5}$ counts per minute per $\mathrm{ml}$.

2. Labelled chylomicrons were obtained from a rat weighing $180 \mathrm{~g}$. The thoracia duct was drained with a double-well catheter [12]. The tube that contained chyle was rinsed with normal saline rather than heparin solution. $8-20$ hours after the operation the rat was fed Altromin " $R$ " enriched with glycerol-tri(9-10- ${ }^{3} \mathrm{H}$-stearate) and unlabelled $\mathrm{TG}$ in order to increase the TG content of the chyle. Chyle was collected at $\mathrm{O}^{\circ} \mathrm{C}$, fibrin was removed mechanically. The chyle was concentrated by centrifugation at $20000 \times \mathrm{g}$ for 1 hour and the top layer resuspended. Additional purification was avoided. The chylomicron suspension used for the metabolic studies contained $29.1 \mathrm{mg}$ of EFA per $\mathrm{ml}$ with a radioactivity of $3.43 \times 10^{4}$ counts per minute per $\mathrm{ml}$. Lipids were extracted from the chyle as described below, and separated by thin layer chromatography [34] on glass plates prepared with silica gel HF 254 (MERck, Darmstadt, Germany) and activated for 1 hour at $120^{\circ} \mathrm{C}$. Chromatography was carried out with petrolether : diethylether:acetic acid (90:10:1, volume). About $92 \%$ of the total radioactivity was recovered in the TG fraction, about $3 \%$ in free fatty acids; the remaining compounds were not identified.

Insulin was injected intramuscularly, the preparations used being crystalline porcine insulin (27.5 u per mg, Farbwerke Hoechst, Hoechst, Germany, Lot No. OP 190260), and "Depot-Insulin" obtained from the same manufacturer.

Studies on tissue uptake: Radioactive-labelled fat emulsion or chylomicrons was injected into a tail vein at a dose equivalent to $100 \mathrm{mg}$ EFA per $\mathrm{kg}$ body weight. The rats were kept in small cages to eliminate metabolic variability due to uncontrolled activity. They were decapitated 15 minutes after injection of the tracer. Blood was collected in heparinized tubes and plasma was obtained after spontaneous sedimentation of the red blood cells. The organs were dissected immediately and rinsed in ice-cold normal saline. Four parts of water were added to 1 part of tissue and the mixture homogenized with a blender (Ultraturrax, Jahnke \& Kunkel, Stauffen, Germany). One volume of plasma or tissue homogenate was extracted for lipid with 25 volumes of acetone:ethanol (1:1) for 1 hour at room temparature. More than $96 \%$ of the lipidsoluble radioactive material was extracted by this procedure. The filtered extracts were transferred to counting vials. Organic solvents were removed in a stream of nitrogen. Radioactivity of the lipid extracts 
(lipid-extractable radioactivity (LER)) was measured in a Liquid-Scintillation-System (Tricarb, Model 314 EX, Packard Instruments Co., La Grange, Illinois, USA. Scintillator: $0.5 \%$ PPO (2,5-Diphenyloxazol), $0.03 \%$ POPOP (1,4 bis 2 (4-methyl-5-phenyloxazolylbenzol)), $2 \mathrm{M}$ ethanol in toluol). Quenching effects were corrected by means of an internal standard. Radioactivity was calculated per $g$ wet tissue and expressed in $\%$ of the dose that had been injected per $\mathrm{g}$ body weight (percent radioactivity). Radioactivity of adipose tissue was also related to the $\mathrm{N}$-content of the tissue. Blood sugar was determined with an Autoanalyzer (Technicon, Frankfurt, Germany) [13] on mixed arterial and venous blood from the tail. Esterified fatty acids (EFA) were determined according to RosentHal et al. [28] and expressed in $\mathrm{mg}$, based on an average molecular weight of the fatty acids of 277 . The $\mathrm{N}$-content of adipose tissue was determined with Nessler's reagent [38] after extraction of lipid. Statistical calculations were based on Student's t-test. Values are expressed as mean $\pm \mathrm{SE}$ unless otherwise stated.

\section{Results}

Normal rats: The concentration of LER in the tissue of normal rats 15 minutes after intravenous injection of fat emulsion or chylomicrons is summarized in Fig. 1. The amount of LFR in the whole organs

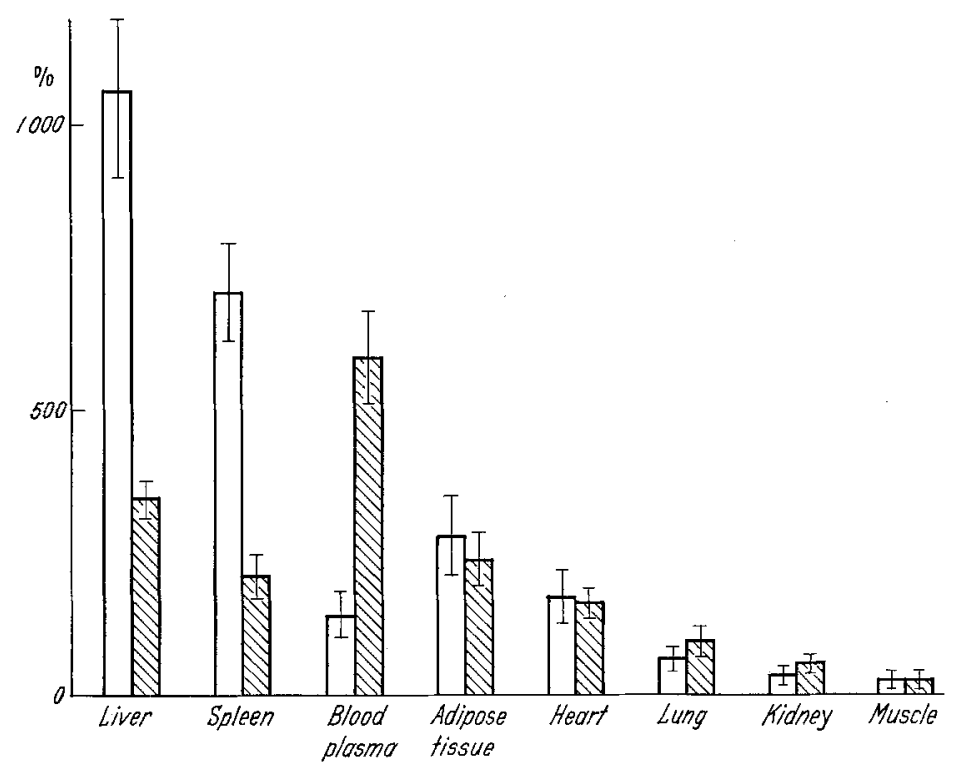

Fig. 1. Lipid-extractable radioactivity in tissue of normal rats, 15 minutes after intravenous injection of labelied fat emulsion or chylomicrons expressed in $\%$ of the dose injected per $\mathrm{g}$ body weight (percent radioactivity)

$$
\square \begin{array}{ll}
\begin{array}{l}
\text { fat emulsion } \\
(n=4)
\end{array} & \begin{array}{l}
\text { chylomiorons } \\
(n=4)
\end{array}
\end{array}
$$

was calculated from the organ weight. The mean values are compared in Table 1 with data published by other authors.
Radioactive lipid of fat emulsion was eliminated from the blood plasma at a greater rate than lipid from chylomicrons. The label was preferentially stored in

Table 1. Lipid-extractable radioctivity in organs of normal rats 15 minutes after intravenous injection of radioactivelabelled fat emulsion or chylomicrons, expressed in \% of the dose injected. Mean of 4 experiments

\begin{tabular}{|c|c|c|c|c|}
\hline \multirow{2}{*}{ Organ } & \multirow{2}{*}{$\begin{array}{c}\% \text { of body } \\
\text { weight }\end{array}$} & \multicolumn{3}{|c|}{ Radioactivity in \% of injected dose } \\
\hline & & Fat emulsion, & & Chylomicrons \\
\hline $\begin{array}{l}\text { blood } \\
\text { plasma }\end{array}$ & $2.9^{1}$ & 3.9 & 17.1 & $38-40^{2} \quad 24.5-35.5^{3}$ \\
\hline liver & 5.5 & 58.8 & 19.2 & $9-14.726 .8-31.1$ \\
\hline $\begin{array}{l}\text { adipose } \\
\text { tissue }\end{array}$ & 8.0 & 22.2 & 18.6 & $18-21.6 \quad 13.3-14$ \\
\hline heart & 0.45 & 0.76 & 0.74 & $0.3-0.36$ \\
\hline spleen & 0.28 & 2.0 & 0.6 & $0.54-0.8$ \\
\hline lung & 0.64 & 0.33 & 0.6 & $0.48-0.5$ \\
\hline kidney & 0.91 & 0.25 & 0.46 & $0.22-0.86$ \\
\hline muscle & 45.0 & 9.0 & 9.9 & $14.8-16.8$ \\
\hline
\end{tabular}

1 Organ weights according to HaGEMANN [15], adipose tissue calculated according to REED et al. [24].

2 Data calculated from BRAgDon and GoRDON [4]; rats fed carbohydrate-rich diet, killed 10 minutes after injection of chylomicrons; $n=2$.

3 Data of Elovsor et al. [10]; rats fasted and refed with carbohydrate-rich diet, killed 20 minutes after injection of chylomicrons; $n=2$.

spleen and liver, which are rich in reticuloendothelial cells. In all other tissues the amount of LER was found to be similar after injection for both fat emulsion or chylomicrons. The LER was almost identical in samples obtained from either the epididymal fat pad or subcutaneous tissue. Peri-renal tissue frequently contained more radioactivity; however, the difference was not significant. The data on adipose tissue refer to the epididymal fat pad.

Diabetic rats: The data on diabetic rats before and after administration of insulin are summarized in Fig. 2, 3, and 4.

In rats injected with fat emulsion (Figure 2) the LER of blood plasma was near normal. Radioactivity was increased in the heart $(0.3<p<0.4)$ but decreased in the liver $(p<0.02)$. A significant decrease of LER was also noted in adipose tissue $(p<0.001)$. As a consequence of fat mobilization the number of cells per $\mathrm{g}$ wet tissue was greater in diabetic animals than in normal ones. This was reflected by the $\mathrm{N}$-content of adipose tissue, which was $14.8 \pm 2.64$ in diabetic and $2.2 \pm 0.59 \mathrm{mg} \mathrm{N}$ per $\mathrm{g}$ wet issue in normal rats (mean $\pm S D)$. Consequently, the comparison of adipose tissue from normal and diabetic rats was based on the $\mathrm{N}$-content of the tissue. A single dose of $1 \mathrm{u}$ of erystalline porcine insulin, injected 30 minutes before administration of the tracer, brought about a twofold. increase of radioactivity in adipose tissue and a $25 \%$ 
increase in the heart. These effects were insignificant. Radioativity in the liver and plasma was unchanged. Treating diabetic rats with insulin for a period of 3 days (cf. legend to Fig. 2) resulted in a significant in-

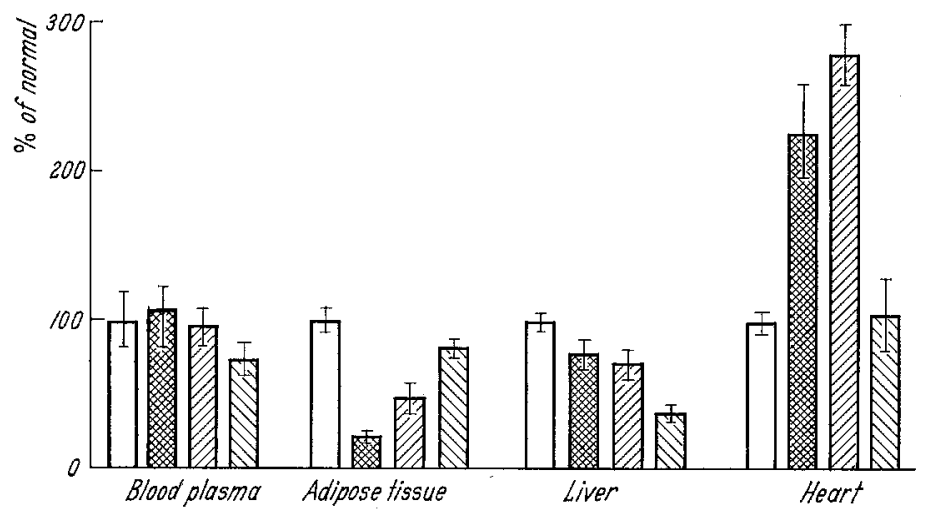

Fig. 2. Lipid-extractable radioactivity (percent radioactivity, ef. Iegend to Fig. 1) in blood plasma, adipose tissue, liver, and heart, 15 minutes after intravenous injection of labelled fat emulsion into normal and diabetic rats before and after treatment with insulin, expressed in \% of normal

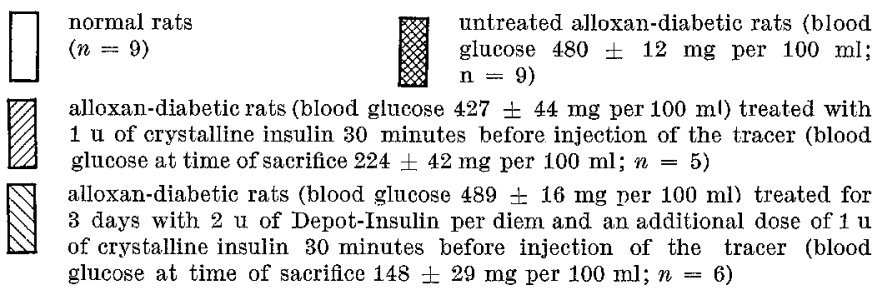

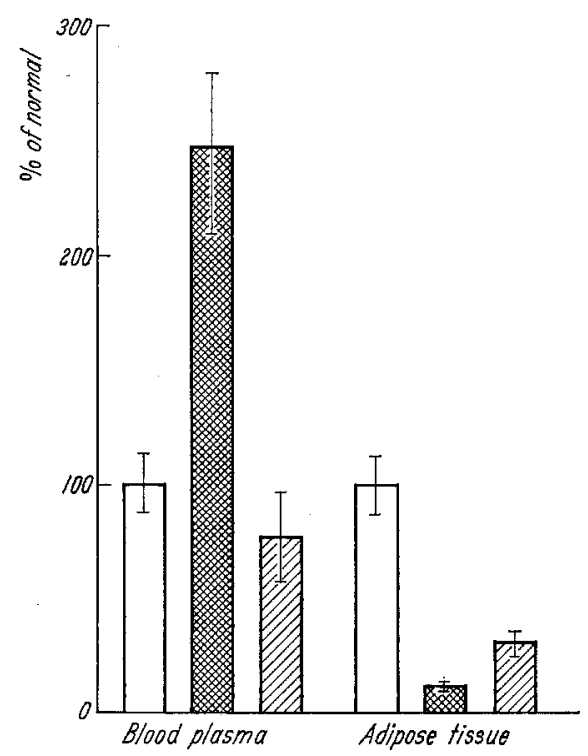

Fig. 3. Lipid-extractable radioactivity (percent radioactivity, cf. Iegend to Fig. 1) in blood plasma and adipose tissue 15 minutes after intravenous injection of labelled chylomicrons into normal and alloxan-diabetic rats be fore and after treatment with insulin, expressed in \% of normal

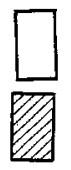

normal rats $(n=4)$

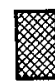

untreated alloxan-diabetic rats (blood glucose $339+$ $21 \mathrm{mg}$ per $100 \mathrm{ml} ; n=6$ )

alloxan-diabetic rats (blood glucose $416+50 \mathrm{mg}$ per $100 \mathrm{ml}$ ) treated with $1 \mathrm{u}$ of crystalline insulin 30 minutes before injection of the tracer (blood glucose at time of sacrifice $218 \pm$ $28 \mathrm{mg}$ per $100 \mathrm{ml} ; n=6$ ). crease in radioactivity in adipose tissue $(p<0.001)$. The concentration of label returned to normal in heart $(p<0.001)$, and was decreased both in the plasma $(0.1<p<0.2)$ and in the liver $(p<0.02)$ ( $p$ of differences between untreated and insulin treated diabetic rats).

In experiments with labelled chylomicrons similar effects of diabetes and insulin were observed in the heart and liver (data not shown). The effects on LER of plasma and adipose tissue were more pronounced than in experiments with TG emulsion (Fig. 3). Plasma radioactivity was significantly increased in diabetic rats $(p<0.05)$. It returned to normal 30 minutes after injection of $1 \mathrm{u}$ of crystalline insulin, the difference between the rats treated with insulin and those not treated being significant $(p<0.02)$. Radioactivity was markedly diminished in adipose tissue of diabetic rats $(p<0.001)$. It was significantly increased after the administration of $1 \mathrm{u}$ of crystalline insulin $(p<0.01)$.

The total LER in the blood plasma and adipose tissue was estimated, based on a blood plasma volume of $2.9 \mathrm{ml}$ per $100 \mathrm{~g}$ body weight and an amount of adipose tissue of $17.8 \mathrm{mg}$ total $\mathrm{N}$ per $100 \mathrm{~g}$ body weight (Fig. 4). In normal rats $35.7 \%$ of the injected radioactivity was recovered, each of the two organs containing about equal amounts of label. The total radioactivity in plasma and adipose tissue of diabetic animals was of similar magnitude;

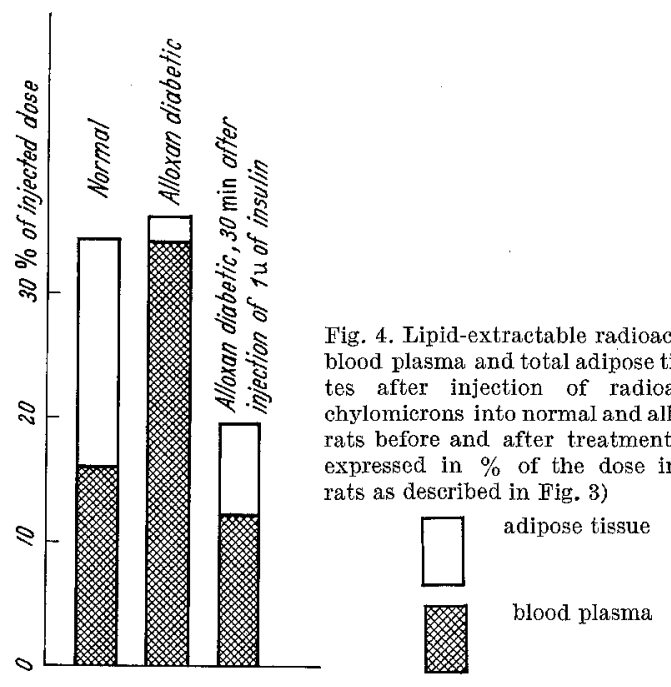

however, $95 \%$ was circulating and only $5 \%$ was stored in adipose tissue. After injection of insulin there was an apparent tendency towards normal.

Starved rats: After deprivation of food for 76 hours the uptake of labelled plasma lipid into adipose tissue was markedly decreased $(p<0.01)$ compared with normal rats and based on the $\mathrm{N}$-content (Fig. 5). 
Thirty minutes after the administration of $1 \mathrm{~g}$ of glucose per kg body weight a twofold increment of adipose tissue radioactivity was found $(p<0.02)$. Exogenous insulin without glucose did not increase LER of adipose tissue of starved rats.

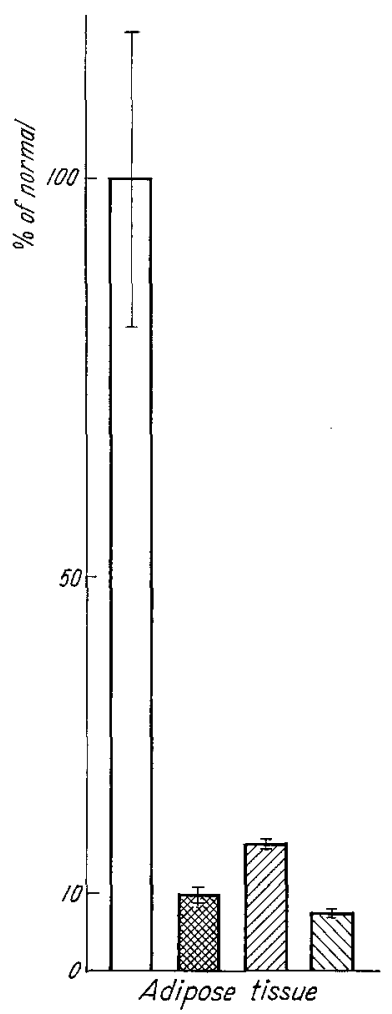

Fig. 5. Lipid-extractable radioactivity (percent radioactivity, cf. legend to Fig. 1) in adipose tissue 15 minutes after intravenous injection of fat emulsion into normal and fasted rats before and after treatment with insulin or glucose, expressed in \% of normal

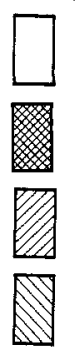

normal rats $(n=7)$

rats fasted for 76 hours $(n=6)$

rats fasted for 76 hours injected with $1 \mathrm{~g}$ per $\mathrm{kg}$ body weight of gIucose 30 minutes before injection of the tracer $(n=6)$

rats fasted for 76 hours injected with 1 u of crystalline insulin 30 minutes before injection of the tracer $(n=4)$

\section{Discussion}

General aspects: Measurements of the uptake of plasma TG by rat tissue were performed employing fat emulsion and chylomicrons injected intravenously. Both tracers were labelled in the saturated fatty acids of the glycerol esters. Therefore measurements of LER in blood plasma and tissue provide a simplified aspect of TG metabolism, without considering the pathways of glyceride-glycerol, the hydrolysis and resynthesis of fatty acid esters (which may re-circulate once they have entered tissue cells) and the degradation of fatty acids to lipid-insoluble products. However, the distribution of labelled lipid between blood plasma and tissue at the end of the experiment can be measured. With this in mind, demonstration of LER in tissues will be referred to as uptake of plasma TG.

Chylomicron $\mathrm{TG}$ were apparently metabolized more rapidly into lipid-insoluble products than TG of the fat emulsion. The reason for this is not quite clear. It may be related to the preferential uptake of emulsified $\mathrm{TG}$ by reticuloendothelial cells [36], or it may be due to the presence in chylomicrons, of labelled lipids other than TG, such as free fatty acids or phospholipids. However, in the preparation used these compounds contained less than $10 \%$ of the total radioactivity. Since fatty acids from fat emulsion were degraded more slowly, this preparation was given preference in the study of TG uptake by tissues. Additional experiments with labelled chylomicrons were included, since fat emulsion may be considered an unphysiologic tracer. In addition, the prolonged halflife of chylomicron TG in blood, reported by others [1] and confirmed in this study, allowed more accurate measurements of their elimination from the blood stream. However, the results obtained with either fat emulsion or chylomicrons were basically identical.

Insulin effects on $T G$ metabolism: As a consequence of the increased pool of circulating lipoproteins a decreased uptake of intravenously injected tracer $T G$ may be expected in the hyperlipaemic stage. The plasma levels of TG were not measured in these experiments, however, since plasma EFA of diabetic rats were found to be increased only by $133 \mathrm{mg}$ per $100 \mathrm{ml}$ the difference of the plasma TG pool was partially compensated by injection of the tracer, which elevated plasma TG levels by more than $300 \mathrm{mg}$ per $100 \mathrm{ml}$.

Plasma TG were taken up by many rat tissues but adipose tissue, heart, and liver were quantitatively of greatest interest. The comparative studies in normal and diabetic rats suggest that hyperlipaemia associated with decompensated diabetes mellitus may mainly be due to a defect in TG uptake by adipose tissue, whereas liver and heart play a minor role only.

Searching for a defect in peripheral TG uptake, decreased LER was found in the liver of diabetic rats (Fig. 2). This may result from re-circulation or limited uptake of lipids as suggested by experiments with perfused livers, which showed that the absolute amount of TG taken up by the organ increased, whereas the $T G$ clearance diminished with increasing $T G$ concentration in the perfusate [21]. The defect of TG uptake by diabetic livers was not restored by exogenous insulin. It is unlikely, therefore, to be due directly to insulin defieiency and seems to be a consequence rather than the basis of diabetic hyperlipaemia.

The concentration of LER was increased in hearts of diabetic animals and returned to normal after administration of insulin (Fig. 2). This finding, which is consistent with the demonstration of increased TG 
concentration in hearts of diabetic rats [8], does not explain the delayed metabolism of plasma $\mathrm{TG}$ in diabetic hyperlipaemia.

About $1 / 5$ of the injected labelled lipid was recovered in adipose tissue of normal rats (Table 1). This organ seems to be of major importance in peripheral TG metabolism, since it is able to store TG proportionally to the intravascular TG concentration, as shown with isolated perfused tissue [21]. Consequently an $80-90 \%$ decrease of TG uptake in diabetic animals (Fig. 2 and 3) may be expected to result in a delayed elimination of TG from blood plasma. This was confirmed in experiments with chylomicrons: the lipid that had not been taken up by the adipose tissue of diabetic rats was found in their plasma. In addition, insulin immediately stimulated TG uptake by adipose tissue and simultaneously normalized the elimination of tracer from the blood stream (Fig. 3 and 4). ${ }^{2}$ This effect of insulin is consistent with experiments of SchWARTz and BotTERMary [32], who employed adipose tissue slices and reported an increased disappearance of EFA from the incubation medium after the addition of insulin.

Since hyperlipaemia of decompensated diabetes mellitus is due to an increment in secondary (endogenous) as well as primary (chylomicron) lipoproteins, it may be questioned whether experiments with exogenous plasma TG (fat emulsion) or primary lipoproteins (chylomicrons) can elucidate its pathogenesis. However, it has been recently shown that fat emulsion injected intravenously may be handled like lipoproteins, since the lipid particles aggregate $\alpha$-and $\beta$-lipoproteins $[18,30,2]$; chylomicrons once injected into the blood stream, acquired properties of secondary particles [3]; and finally, adipose tissue stored TG without regard to the $\mathbf{T G}$ carrier $[19,20]$. Therefore, it is reasonable to suggest that the uptake of $T G$ derived from both primary and secondary lipoproteins by adipose tissue is insulin-dependent. TG uptake by adipose tissue seems to represent an important factor in the regulation of the plasma TG level. The reversible defect of this metabolic process observed in decompensated diabetes mellitus may provide the major basis of diabetic hyperlipaemia.

Mechanism of the insulin effect: The mechanism of TG uptake by adipose tissue is not yet fully understood. It has been postulated that $T G$ are hydrolyzed before fatty acids are taken up by the cells. Consequently the rate of plasma "TG" uptake would depend on the lipoprotein-lipase activity [25]. Since the activity of the enzyme may be regulated by insulin [17, $31,5]$ this hypothesis would provide an explanation for the increment in $\mathrm{TG}$ uptake effected by insulin.

\footnotetext{
${ }^{2}$ Elimination of tracer from blood plasma was more pronounced than was expected from the increment in TG uptake by adipose tissue. This suggested that, to some extent, lipid uptake by tissue other than adipose tissue, such as working skeletal muscle, which was not studied, might also have been affected by insulin.
}

However, as reviewed by SHAPIRo [33] and recently discussed with respect to diabetic hyperlipaemia [16], the role of the lipoprotein-lipase in plasma TG metabolism is questionable. For the time being it seems likely that TG molecules are taken up by adipose tissue without hydrolysis. Once they have entered the cell, glycerol esters may be hydrolyzed and fatty acids re-esterified before they are finally deposited $[26,33]$. Since the latter process depends on carbohydrate metabolism [22], insulin may enhance TG uptake by stimulating glucose metabolism, thus providing energy for the activation of fatty acids as well as a-glycerophosphate as accoptor of fatty acid CoA compounds. This view would also be consistent with the finding that decreased TG uptake in starved rats, reported by other investigators [4] and confirmed in this study, was not stimulated by exogenous insulin, but by injection of glucose.

Acknowledgements. The authors wish to express their gratitude to Drs. H.J. Thomasson and J.J. GotTenBoos (Unilever Research Laboratories, Vlaardingen, The Netherlands) for their help with the catheterization of the thoracic duct of rats. They wish to thank Dr. B. BRAUN (Melsungen, Germany) for the preparation of radioactivelabelled fat emulsion and A. ENDERs (Farbwerke Hoechst, Hoechst, Germany) for providing highly purified insulin. The technical assistance of Miss W. Bertram is greatly appreciated.

The work was supported by "Landesamt für Forschung des Landes Nordrhein-Westfalen" (III/2-03$40 / 3000)$ and by "Deutsche Forschungsgemeinschaft" (Ja 123/3).

\section{References}

[1] Belfrage, P., B. Edgren and T. Olivecrona: The tissue distribution and motabolism in the rat of intravenously injected labeled fat emulsions. Acta physiol. scand. 62, 344-351 (1964).

[2] BiERman, E.L., and J.T. HamiIn: A preparation of C14-labeled triglyceride in plasma as a tracer for plasma particulate fat. Proc. Soc. exp. Biol. (N.Y.) 109, $747-750$ (1962).

[3] - , and D.E. Strandness, JR.: Formation of secondary fat particles from lymph chylomicron in the dog. Amer. J. Physiol. 210, 13 - 18 (1966).

[4] Bragdon, J.H., and R.J. Gordon: Tissue distribution of $\mathrm{C}^{14}$ after the intravenous injection of labeled chylomicrons and unesterified fatty acids in the rat. J. clin. Invest. 37, 574-578 (1958).

[5] CAHILL, G.F., JR.: Uptake and release of lipid by adipose tissue. In: H.C. Meng, Edit. : Proc. Internat. Symp. Lipid Transport. Springfield, Illinois, Charles, C. Thomas, 1964 .

[6] CampbelL, J.: Hyperlipidemia with ketoacidosis. Metabolism 14, 1243-1254 (1965).

[7] Canzler, H., and H. Glatzzel: Auswirkungen von Dauerkostformen verschiedenen Fettgehaltes auf den menschlichen Organismus. Med. Pharmakol. Exper. $12,145-156(1965)$.

[8] Denton, R.M., and P.J. RaNDle: Hormonal control of lipid concentration in rat heart and gastrocnemius. Nature (Lond.) 208, 488 (1965).

[9] Deues, H.J., JR.: The lipids. New York, Interscience Publ. Inc., Vol. II, p. 447 ff., 1955.

[10] Elovson, J., T. Olivecrona and P. Belfrage: Metabolism in the rat of chyle obtained after feeding hydrogenated coconut oil labeled with stearic acid. Biochim. biophys. Acta 106, 34-44 (1965). 
[11] Fredrickson, D.S.: Essential familial hyperlipidemia. In: Stanbury, J.B., D.S. Fredrickson and J.B. WYNGAARDEN, Edits.: The metabolic basis of inherited disease. New York, McCraw-Hill, p. $510 \mathrm{ff}$. , 1960 .

[12] Gotrenboos, J.J., and H.J. Thomassox: The fatty acid composition of thoracic lymph fat of rats fed single triglycerides. In : Frazme, A.C., Edit.: Biochemical problems of lipids. Biochim. biophys. Acta Library Vol. 1, 272-279 (1963).

[13] Grady, H.J., and M.A. Lamar: Glucose determination by automatic chemical analysis. Clin. Chem. $5,542-550(1959)$.

[14] Gries, F.A., S. Potтhofr and K. JAhnke : Effects of insulin on the metabolism of plasma triglycerides. Excerpta Med. Int. Congr. Series 74, 12 (1964) (Abstract).

[15] HagemanN, E.: Ratte und Maus, Versuchstiere in der Forschung. Berlin, W. de Gruyter, p. 122-125 1960.

[16] Jones, D.P., G.R. Plotkin and R.A. ARky: Lipoprotein lipase activity in patients with diabetes mellitus, with and without hyperlipemia. Diabetes 15, $565-570(1966)$.

[17] KESSLER, J.I.: Effect of insulin on release of plasma lipolytic activity and clearing of emulsified fat intravenously administered to pancreatectomized and alloxanized dogs. J. Lab. clin. Med. 60, 747-755 (1962).

[18] Mann, G.E., M.L. Brown, I.L. DiTrepani and W.S. SINGLEToN: Interactions in fat emulsion-protein systems. Metabolism 10, 859-868 (1961).

[19] MARKsomerd, L., and F. SHAFRTR: Assimilation of lipoprotein triglyceride in vitro: comparison of various adipose tissues and lipoproteins and effect of lipoprotein lipase inhibitors. Israel J. Chem. 1, 205 (1963), cit. ref. 33 .

[20] - Incorporation of lipoprotein-borne triglycerides by adipose tissue in vitro. J. Lipid Res. 6, 247-257 (1965).

[21] Morris, B. : Some factors affecting the metabolism of free fatty acids and chylomicron triglycerides by the perfused rat's liver. J. Physiol. (Lond.) 168, 584$598(1963)$.

[22] Raben, M.S., and C.H. HollenberG: Effect of glucose and insulin on the esterification of fatty acids by isolated adipose tissue. J. clin. Invest. 39, 435$439(1960)$.

[23] Reaven, G.M., D.B. Hils, R.C. Gross and J.W. FarquHAR: Kinetics of triglyceride turnover of very low density lipoproteins of human plasma. J. clin. Invest. 44, 1826-1833 (1965).

[24] ReEd, L.L., F. YamaGUChI, W.E. Andersen and L.B. Mendel: Factors influencing the distribution and character of adipose tissue in the rat. J. biol. Chem. 87, 147-155 (1930).
[25] Robinson, D.S.: The clearing factor lipase and its action in the transport of fatty acids between the blood and the tissues. Advanc. Lipid Res. 1, 134$182(1963)$

[26] RODBELL, M. : The removal and metabolism of chylomicrons by adipose tissue in vitro. J. biol. Chem. 235, $1613-1620(1960)$.

[27] -, and R.O. Scow: Chylomicron metabolism:uptake and metabolism by perfused adipose tissue. In: RENOLD, A. E. and G.F. CATILL, JR.; Edits. : Handbook of Physiology, Sect. 5, Adipose Tissue. Washington, Amer. Physiol. Soc., p. 491-498, 1965.

[28] Rosenthal, H.L., M.L. Phluke and J. Callerami: The colorimetric estimation of serum fatty acids. Clin. chim. Acta 4, 329-333 (1959).

[29] Ryan, W.G., and T.B. Schwartz: Dynamics of plasma triglyceride turnover in man. Metabolism 14, $1243-1254$ (1965).

[30] SCANO, A., and I.H. PAGE: Recombination with lipids of the lipid-free protein from canine serum (d $\left.1.063-1,21, \alpha_{1}\right)$ lipoprotein. J. Lipid Res. 2, $161-$ 168 (1961).

[31] Schnatz, J.D., and R.H. Wriliams: The effect of acute insulin deficiency in the rat on adipose tissue lipolytic activity and plasma lipids. Diabetes 12, $174-178$ (1963).

[32] SchWARz, K., and P. BotTERManN : Über die Wirkung des Insulins auf die Fettaufnahme durch das Fettgewebe. E. KLEIN, Edit. Schilddrüsenhormone und Körperperipherie-Regulation der Schilddrüsenfunktion. Berlin, Springer-Verlag, p. 266-268, 1964.

[33] Shaptro, B. : Triglyceride metabolism. Renold, A. E., and G. F. CAHILE, Jr. Edits. : Hand book of Physiology, Sect. 5, Adipose Tissue. Washington, Amer. Physiol. Soc., p. 217-224, 1965.

[34] STAHL, E. Edit.: Duennschicht-Chromatographie. Berlin, Göttingen, Heidelberg, Springer 1962.

[35] WADDELL, W.R., and R.P. GEYER: Effect of insulin on clearance of emulsified fat from the blood in de pancreatized dogs. Proc. Soc. exp. Biol. (N.Y.) 96, $251-255$ (1957).

[36] - - E. Clarke and F.J. StTare: Function of reticuloendothelial system in the removal of emulsified fat from blood. Amer. J. Physiol. 177, 90-94 (1954).

[37] Winegrad, A.I.: Adipose tissue in diabetes. ReNOLD, A.E. and G.F. CAHuLL, JR. Edits.: Handbook of Physiology, Sect. 5, Adipose Tissue. Washington, Amer. Physiol. Soc. p. 319-330, 1965 .

[38] WONG, S.Y.: The use of persulfate in the estimation of nitrogen by Folin's direct Nesslerization method. J. biol. Chem. 55, $431-435$ (1923).

Dr. F.A. Gries

II. Med. Klinik und Poliklinik

der Universität Düsseldorf

4000 Düsseldorf, Moorenstr. 5 